\title{
Development of the Lower Sacramento Valley Flood-Control System: Historical Perspective
}

\author{
L. Allan James ${ }^{1}$ and Michael B. Singer ${ }^{2}$
}

\begin{abstract}
Natural physical conditions and the politics of flood management provide the historical context for structural flood control that underlies modern flood hazards in the Sacramento Valley. The valley is a broad, low plain with backswamp basins that were frequently inundated prior to Anglo-American settlement, continuing until the modern flood-control system was established. Early attempts to emulate the Mississippi River single-channel levee strategy failed repeatedly in the Sacramento Valley due to high flow variability, mining sedimentation, lack of a coordinated levee system, and the inability of the main channels to carry most of the flood flows. Hydraulic mining caused massive sedimentation in major east-side tributaries, such as the Feather, Yuba, Bear, and American Rivers, and in the Sacramento River below the Feather River confluence. This sedimentation led to a flood-control design that relied on levees with narrow cross-channel spacings to promote channel scour and facilitate navigation. Even without sedimentation, floods were not contained within channels, but were largely conveyed through a system of low-land basins. In the early twentieth century, an innovative channel bypass system was adopted that emulates the natural system by routing excess flood waters over a series of weirs and through broad, channelized bypasses that cross the basins. This system has been successful in reducing the extent of frequent inundations of broad lowland areas of the valley. It is in need of maintenance and improvement, however, and cannot eliminate the risk of future flooding in low areas behind levees that are being rapidly developed.
\end{abstract}

DOI: 10.1061/(ASCE)1527-6988(2008)9:3(125)

CE Database subject headings: Floods; Flood plains; Sediment deposits; Channelization; Levees; Hazards; California; History.

\section{Introduction}

Two of the most flood-prone cities in the USA are New Orleans and Sacramento (O'Neill 2006; SAFCA 2008). Ironically, the lower Mississippi and Sacramento River Basins were the first major projects to receive federal funding for flood control (O’Neill 2006). Federal support for flood protection in the Sacramento Valley was justified by the need to protect navigation, especially after a major episode of hydraulic gold mining in the Sierra Nevada foothills. Massive sedimentation from mining favored a flood-control system consisting of self-scouring channels, so levees were engineered to maximize flood depths with narrow lateral spacings; i.e., constricted cross-channel spacings between levees on opposite sides of the river. The natural, presettlement Sacramento River carried a small percentage of the down-valley flood flows, relying on adjacent low-lying basins to carry a majority of the discharge. This factor, coupled with extreme variability of the discharge regime and high peak discharges, imposed serious limits on the use of levees alone to constrain flows into a

${ }^{1}$ Professor, Geography Dept., Univ. of South Carolina, Callcott Bldg., 709 Bull St., Columbia, SC 29208. E-mail: Ajames@mailbox.sc.edu

${ }^{2}$ Lecturer, School of Geography and Geosciences, Univ. St. Andrews, Irvine Building, North St., St. Andrews KY16 9AL Fife, Scotland, UK, and, Institute for Computational Earth System Science, Univ. of California Santa Barbara. E-mail: bliss@icess.ucsb.edu

Note. Discussion open until January 1, 2009. Separate discussions must be submitted for individual papers. To extend the closing date by one month, a written request must be filed with the ASCE Managing Editor. The manuscript for this paper was submitted for review and possible publication on August 13, 2007; approved on March 14, 2008. This paper is part of the Natural Hazards Review, Vol. 9, No. 3, August 1, 2008. CASCE, ISSN 1527-6988/2008/3-125-135/\$25.00. single channel on the Sacramento River. This tectonically influenced valley required a more innovative approach to flood control that incorporated natural geomorphic features into the design. This paper describes the Sacramento Valley flood-control system from a historical, geographic, and institutional perspective. It addresses the gradual development of an integrated flood management strategy that persists to this day. A companion paper addresses the status of this flood control system within the context of its natural hydrogeomorphic setting (Singer et al. 2008).

\section{Basin Physically Predisposed to Frequent, Extensive Flooding}

The Central (or Great) Valley is comprised of the Sacramento Valley to the north, the San Joaquin Valley to the south, and the Sacramento-San Joaquin-Delta where they join. Geographically, the Sacramento Valley extends from the broad alluvial lowlands below Chico to the river mouth (Thompson 1961) (Fig. 1). It is dominated by a broad, low-lying plain, bounding the aggraded Sacramento River, much of which has been prone to extensive flooding throughout recent geologic time. Frequent lowland inundation prevailed under natural conditions due to high flow variability and limited channel conveyance capacities. Main channels of the valley once carried large amounts of sediment and thereby constructed broad natural levees from 2-7 m high parallel to the banks (Bryan 1923). Extensive lowland basins; i.e., the Butte, Colusa, Sutter, American, Sacramento, and Yolo Basins are natural backswamp areas outboard of natural levees at the lowest elevations in the Sacramento Valley [Fig. 1(c)]. Under natural conditions, the basins were filled when floods broke through natural levees at crevasses. Sealing off this lateral connectivity between the rivers and basins was a central issue in early flood management policy debates. 


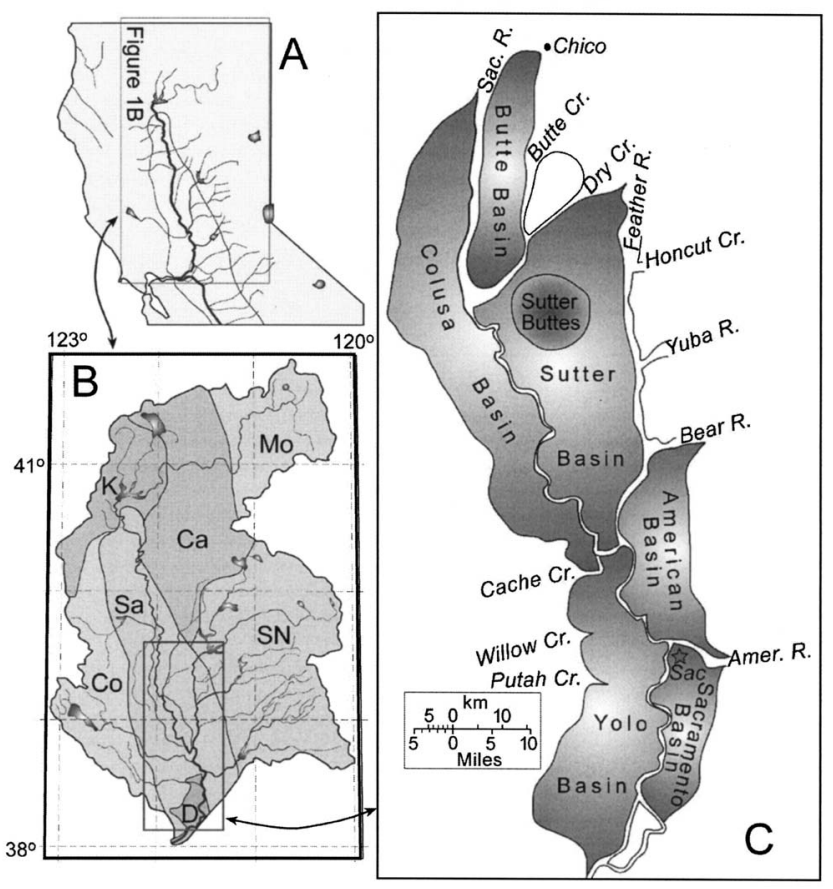

Fig. 1. Maps of Sacramento Valley; (a) Northern California; (b) physiography of Sacramento Basin: $\mathrm{Mo}=$ Modoc Plateau, $\mathrm{K}=$ Klamath Mountains, $\mathrm{Ca}=$ Cascade Mountains, $\mathrm{Sa}=$ Sacramento Valley, $\mathrm{SN}=$ Sierra Nevada, $\mathrm{Co}=$ Coastal Range, $\mathrm{D}=$ Delta [adapted from Fenneman and Johnson (1946) and USGS (2007)]; and (c) natural basins in Sacramento Valley [adapted from Gilbert (1917)]

Prior to flood control, the lower Sacramento River and the lower Feather River, its largest tributary, carried only a small proportion of their peak discharges during major floods. It was noted in the early 20th century that the channel capacity of the Sacramento River actually decreased downstream between Colusa and the mouth of the Feather River to $10 \%$ of its flood discharge (Gilbert 1917, p. 15) for structural reasons (Singer et al. 2008). Geologically, the Sacramento Valley is a tectonic trough that receives sediment from the mountains on all sides except the south (Hackell 1966). The alluvial fill is on the order of $70 \mathrm{~km}$ wide at the surface. Prior to artificial levees and other engineering works, low, frequently inundated surfaces extended tens of kilometers wide. These swamplands are shown on early maps as tulares, which indicates contemporary knowledge of flood hazards in the region, although flood hazards before the gold mining period were often neglected erroneously by early settlers and flood managers (Thompson 1960).

\section{Hydrologic Variability and Early Floods}

Geomorphic and climatic conditions combine to create a physical system that can quickly generate large volumes of surface runoff. For example, warm, moist air born in the mid-Pacific reaches Northern California when high pressure ridges collapse, generating large amounts of runoff in the mountains, especially the Sierra Nevada (USACE 1998). Flood waves produced by these "pineapple express" storms are quickly conveyed through steep, narrow canyons and converge on the flat plains of the Sacramento Valley. These events generate flood discharges that are disproportionately large compared to the mean annual floods of the rivers. Initial flood-control policies of the U.S. Army Corps of Engineers
(COE) followed strategies employed in the Mississippi River, but the hydrology and geomorphology of the Sacramento Valley rivers are different. The lower Mississippi drains a much larger basin and has larger flows but flood peaks arrive slower and are smaller in proportion to mean flows than in the Sacramento Valley.

Northern California was settled rapidly by Americans and Europeans beginning in the 1850s during the Gold Rush. Little was known of the natural landscapes or hydrologic systems, and the dry Mediterranean summers, when most settlers arrived, maintained deceptively low river flows. This must have led to an underestimation of winter flood stages and a tendency to dismiss the observed winter floods as anomalies. Unlike in the eastern United States and Latin America, indigenous people in California were not often consulted about the natural history of the region during the Gold Rush fervor. Accounts of the indigenous Indians later revealed knowledge of recurrent extensive flooding in the valley (Ellis 1939, pp. 139-140). Moreover, early explorers had recognized evidence of extreme floods in the Sacramento Valley (Thompson 1960). Had this been widely understood at the time of settlement, flood-avoidance planning may have received more attention. Instead, the frequency of overbank flows that extended widely and filled the basins was grossly underestimated. Settlement concentrated along lowland rivers due to the rapid influx of settlers, dominance of water transportation, economic incentives of placer gold, lack of perception of flood hazards, and the great fertility of floodplain soils. As knowledge of frequent floods grew from direct experience, the initial response was reactionary rather than judicious or analytical: protection of existing settlements by building levees was a high priority. In hindsight, the low topographic positions of the initial settlements and the high range of interannual flood stages reveal the flaws of the early flood-control practices and how they led to a reliance on repetitive increases in size, extent, and expense of flood-control levees in the valley.

Floods in the early 1850 s often resulted in communities making a commitment to levees without considering alternatives such as relocating to higher ground (Kelley 1989). The tacit decision to stand and fight nature is clearly shown in the histories of Sacramento and Marysville. Following a winter flood in the city of Sacramento in 1850, spring flood waters rose rapidly, threatening to flood the city again. Volunteers built a makeshift levee during the storm and warded off the flood. Subsequently, the people of Sacramento voted to build a 3-foot high levee around the city, which held back flood waters later that year but failed in December 1852 (Kelley 1989). Incremental enlargement and extension of the Sacramento levee system continued for 150 years as the magnitude-frequency relationship of floods on the Sacramento and American Rivers continued to be underestimated. By the 1990s, a reassessment of flood hazards on the lower American River reveals how even the early technical calculations of flood probabilities were too low for climatic reasons (NRC 1995, 1999; James 1999).

Storms in 1852 and 1853 also flooded the city of Marysville and led to a protracted period of levee construction on the Feather and Yuba Rivers. The March 1853 flood inundated downtown Marysville to a depth of almost a meter. Since it was a much smaller city than Sacramento, flood control in Marysville required a less extensive levee system, and by the 1870s, Marysville was completely encircled. The importance of the levees to maintaining the city at that location was expressed by a prominent levee commissioner:

"The city's levee is the most important and vital thing the city 


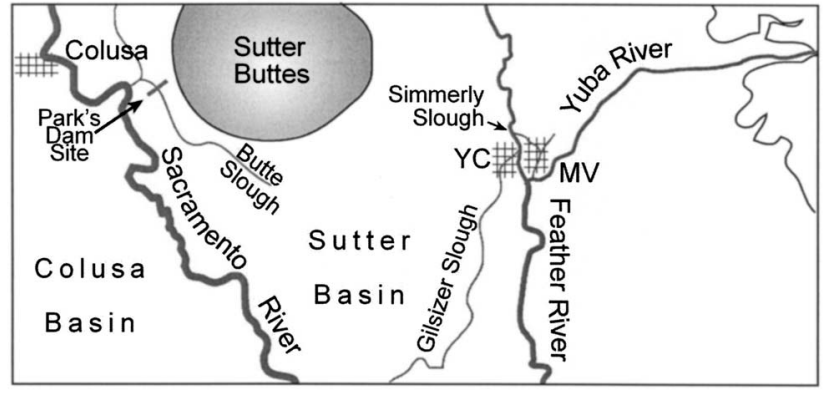

Fig. 2. Map showing early sites of dammed distributary channels. Dam at mouth of Gilsizer Slough in Yuba City (YC) failed in December 1867. Simmerly Slough through Marysville (MV) was dammed by levees that encircle Marysville. Park's Dam on Butte Slough below Colusa would have prevented diversion of much Sacramento River flow into Sutter Basin [adapted from Kelley (1989)].

owns; it also is the most costly thing the city owns, representing an expenditure of over one million dollars ..." (Ellis 1939, p. 304)

\section{“Levee-Wars” Era}

Early levee engineering in the Sacramento Valley failed to consider the rivers as integrated systems. Levees were often poorly designed, with little hydrologic knowledge of the watershed, hydraulic understanding of how rivers behave, or the geotechnical properties of construction materials. As knowledge of flood frequencies in the valley grew gradually from experience of repeated levee failures and flooding, levees were extended farther along main channels, tributary confluences, and across crevasses, and were built incrementally higher. Persistent underestimation of flood variability led to inadequate structural design and the inability to anticipate the economic commitment necessary for a structural flood-control system that could contain the entire flood discharge of the Sacramento River within its banks. Until 1876, a period of levee wars prevailed in which individual land owners or local levee districts acted with impunity to construct levees and dam crevasses to prevent local flooding of low-lying lands (Kelley 1989). The channels were naturally adjusted to substantial flow diversions into flood basins, so eliminating distributary flows forced more water into the main channel, which raised flood stages and velocities and often caused more severe flooding elsewhere. Levee districts competed among themselves, often knowingly exacerbating flooding on neighboring lands. In spite of the common knowledge that new levees could cause severe damage to others, the frontier ethos justified injury to others by the need for individuals or communities to look out for themselves (Kelley 1989). Victims of exacerbated flooding lacked legal recourse until the late 19th century.

Crevasses were dammed at several points on the Sacramento and Feather Rivers in an attempt to prevent flows from main channels to the adjacent low-lying basins. For example, in November 1867, Gilsizer Slough, linking Feather River to Sutter Basin, was dammed to protect Yuba City and Sutter Basin (Fig. 2). In December of the same year, the dam failed, causing a damaging flood downstream along the Slough (Kelley 1989). Similarly, Simmerly Slough, which ran from the Feather River through Marysville to the Yuba River, was dammed off at its north and south ends in 1857 leaving only Ellis Lake in downtown Marysville as a legacy of the former waterway (Ellis 1939).
Butte Slough, a key outlet connecting the Sacramento River to Sutter Basin (Fig. 2), was dammed in 1871 by William Parks, a large swampland owner in Sutter Basin, to the consternation of many landowners outside of Sutter Basin. In December 1871, as waters rose dangerously in the backwater areas, the dam was dynamited by armed vigilantes who overpowered the guards at gunpoint (Kelley 1989). Parks rebuilt the dam with increased security and during the rising limb of the next storm, as higher stages threatened severe flooding above Colusa, the dam failed causing tragic damages to farmers downstream along Butte Slough. Parks' attempt to rebuild the dam again was thwarted in 1876, by Judge Keyser of the 10th District Court of California, who enjoined not only Parks' dam, but also any such project that endangered others. This decision was upheld by the California Supreme Court and marks the end of the levee-war era, at least with regard to large new independent levee projects that sought to redirect major river flows (Kelley 1989). Although damage to others caused by damming channels was henceforth a legal consideration, the practice of building artificial levees to restrict overflows was by no means over. In fact, flood management policy continued for several decades to rely on levees to contain flows within main channels.

\section{Exacerbated Flood Hazards: Hydraulic Gold-Mining Sedimentation}

Hydraulic mining was invented in the mountains of the Yuba River Basin in 1853 and produced vast amounts of sediment through the 1870s (Gilbert 1917; James 1989, 1999; Greenland 2001). Most of this sediment initially remained in the mountains, but by 1862 , torrents of sediment were being delivered to the valley and causing rapid aggradation and exacerbation of flooding along valley rivers (i.e., on the lower Yuba, Feather, Bear, American, and Sacramento Rivers). Contrary to beliefs of late 19th century settlers in the valley, flood hazards in the valley had been extreme prior to the delivery of hydraulic mining sediment, which simply exacerbated an already dangerous condition (Thompson 1960). Although mining sediment was not the root cause of flooding throughout the valley, sedimentation greatly increased flood hazards in certain rivers, including the main Sacramento River from the Feather River confluence to the Sacramento-San Joaquin Delta (Heuer 1891). Flooding increased due to rising channel beds, locally coarsened bed materials, and decreased channel gradients and flood conveyance capacity.

Sediment production accelerated through the 1870 s, and by ca. 1905 , an estimated 1.1 billion $\mathrm{m}^{3}$ of hydraulic mining sediment had been produced in these river basins (Table 1). The Yuba, Bear, and Feather Rivers received the highest mining sediment loads, so the Sacramento River was severely impacted below the confluence of the Feather River. These changes to channels that already lacked the capacity to contain large floods resulted in increased flood frequencies, repeated bank and levee failures, and severe flood damages. Attributing channel changes and increased flood hazards to hydraulic mining was contested during the mining period, as litigation mounted between farmers in the valley and miners in the mountains (Kelley 1956, 1959). This debate was elucidated by a court case in the late 1870s (Keyes 1878) and was largely resolved in 1880 when Wm. Hammond Hall, the State Engineer, released a report based on extensive topographic surveys that provided clear evidence of severe channel aggradation and ongoing sedimentation from hydraulic mining based on scientific measurements (Hall 1880; Crawford and Herrick 2006). One obvious implication of the massive amounts of mining sedi- 
Table 1. Sediment Production Statistics by Basin [Source: James et al. (2007), Based on the Gilbert (1917) Recommended 1.51 Adjustment to Previous Estimates]

\begin{tabular}{|c|c|c|c|c|c|c|c|}
\hline \multirow[b]{2}{*}{ Basin } & \multirow{2}{*}{$\begin{array}{l}\text { Drainage } \\
\text { area } \\
\left(\mathrm{km}^{2}\right) \\
\end{array}$} & \multirow{2}{*}{$\begin{array}{l}\text { Volume } \\
\text { produced } \\
\left(\mathrm{m}^{3} 10^{6}\right)\end{array}$} & \multirow{2}{*}{$\begin{array}{c}\text { Volume produced } \\
\text { per year } \\
\left(\mathrm{m}^{3} \mathrm{yr}^{-1}\right)\end{array}$} & \multirow{2}{*}{$\begin{array}{c}\text { Volume/drainage } \\
\text { area } \\
(\mathrm{mm})\end{array}$} & \multicolumn{2}{|c|}{ Mass produced } & \multirow{2}{*}{$\begin{array}{l}\text { Specific production } \\
\begin{array}{c}p=2.2^{\mathrm{a}} \\
\left(t \mathrm{~km}^{-2} \mathrm{yr}^{-1}\right)\end{array}\end{array}$} \\
\hline & & & & & $\begin{array}{c}p=2.2^{\mathrm{a}} \\
\left(t 10^{6}\right)\end{array}$ & $\begin{array}{l}\text { Mass/year } \\
\left(10^{6} t \mathrm{yr}^{-1}\right)\end{array}$ & \\
\hline $\begin{array}{l}\text { Feather Basin } \\
\text { at Yuba City }\end{array}$ & 10,301 & 77 & 2.5 & 7.4 & 168 & 5.4 & 527 \\
\hline Yuba Basin & 3,499 & 523 & 16.9 & 149.6 & 1,151 & 37.1 & 10,616 \\
\hline North Yuba & 1,351 & 165 & 5.3 & 122.4 & 364 & 11.7 & 8,683 \\
\hline Middle Yuba & 536 & 109 & 3.5 & 203.7 & 240 & 7.7 & 14,455 \\
\hline South Yuba & 988 & 165 & 5.3 & 167.2 & 363 & 11.7 & 11,866 \\
\hline Deer Creek & 233 & 29 & 0.9 & 126.4 & 65 & 2.1 & 8,968 \\
\hline Bear Basin & 1,143 & 271 & 8.7 & 236.8 & 596 & 19.2 & 16,807 \\
\hline American Basin & 5,014 & 197 & 6.3 & 39.2 & 433 & 14.0 & 2,783 \\
\hline North Fork & 900 & 164 & 5.3 & 181.7 & 360 & 11.6 & 12,895 \\
\hline Middle Fork & 1,586 & 33 & 1.1 & 20.9 & 73 & 2.4 & 1,486 \\
\hline Totals: & 19,957 & 1,067 & 34.4 & 53.5 & 2,348 & 75.74 & 3,795 \\
\hline
\end{tabular}

${ }^{\mathrm{a}}$ Density $(p)$ of mined rock (mostly conglomerates and volcanics) assumed equal to $2.2 \mathrm{~g} / \mathrm{cm}^{3}$.

ment documented by Hall's landmark study was the unavoidable need for a coordinated flood-control system in the valley (Kelley 1989).

The dispute over the legality of hydraulic mining sediment production was largely resolved by a federal court in the Sawyer decision of 1884, that decided against the miners and enjoined hydraulic gold mining in tributaries to navigable rivers. Although sediment production from mines dropped precipitously after 1884 , sediment storage was widespread and remobilization of this sediment continues to this day (Fig. 3) and adds uncertainty to the behavior of the flood-conveyance system. Sediment delivery from the mountains to the valley continued until dams were constructed on major rivers, beginning in 1928 and continuing until 1967 when Oroville Dam on the Feather River was completed. Redistribution of historical sediment-largely hydraulic mining sediment-is discussed further in a companion paper (Singer et al. 2008).

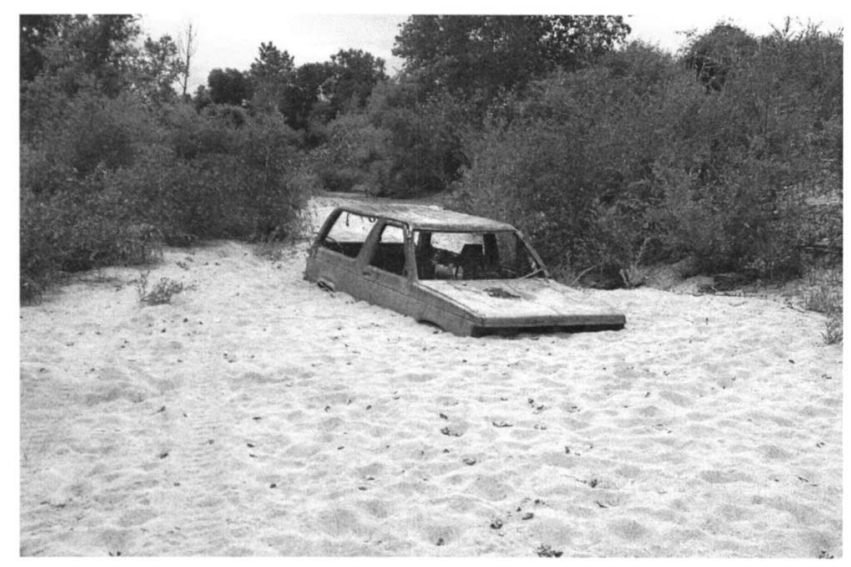

Fig. 3. Evidence of recent sediment reworking in the lower Yuba River is abundant. This sediment can exacerbate flooding by raising flood stages or causing channels to shift location during floods. Photograph by first author, June 2006.

\section{Conflicting Strategies for Coordinated Flood Control}

Through the late 19th century, it became increasingly clear that piecemeal levee construction was not the answer to flood management in the valley. This realization had been inevitable in the face of the Hall (1880) report that revealed the need for centralized control of the massive amount of sediment coming down from the mines. A coordinated system would require some degree of state and federal authority, however, and the debate between centralized versus local control of resource management was politically charged. The concept of federal funding for flood control was controversial in the late 19th century (Arnold 1988).

Flood-control policies in the Sacramento Valley were greatly influenced by developments in the lower Mississippi Valley, the first major river basin to receive federal funding for river management. The early emphasis of federal involvement had been on navigation improvements, following the Supreme Court ruling in Gibbons versus Ogden based on the commerce clause of the U.S. Constitution. The flood-control strategy that emerged in the Mississippi River was detailed in an influential engineering report (Humphrey and Abbot 1861). It used levees with limited crosschannel spacings to maximize flood depths, encourage channelbed scour, and improve navigation. Levees also protected agricultural interests, so flood control was a tangible benefit of this strategy, which appealed to the growers and river engineers in California.

With the successful procurement of federal funding for navigation and flood-control projects in the lower Mississippi, the call for similar federal support for the Sacramento Valley was justified by the need to protect navigation from sedimentation in a productive agricultural region. The strategy was politically persuasive due to the public cry for flood protection. Large landowners in the Sacramento Valley, many of whom obtained large tracts of land in Sutter and Colusa Basins by way of the Swamplands Act, advocated protecting these lands from flooding (Kelley 1989). However, substantial differences in the geomorphology and hydrology of the two basins, described earlier, were not fully appreciated and resulted in the ultimate failure of the single-channel strategy. 


\section{Early Concepts and Policies}

Will Green, editor of the Colusa Sun newspaper and a former state representative, argued for decades against piecemeal levee projects, predicting correctly that a policy of uncoordinated levee construction would fail after tremendous expense and tragic personal losses. Later, when a broadly coordinated approach to levee development became accepted, Green argued against the prevailing single-channel policy advocated by the COE and large swampland owners. Green had been the first to recommend routing flood flows through basins to reduce flood stages on the main channel. He recognized in the 1860s that the main channel of the Sacramento River had never carried the full flow and could not be made to carry the full flow even if no mining sediment had been introduced. He advocated the controlled use of basins as a means of reducing flows in the main channel (Kelley 1989).

In the 1870 s, most advocates of a centrally designed and managed, integrated flood-control system in the valley favored a single-channel conveyance system. General Barton S. Alexander of the COE conducted an irrigation survey of the Sacramento and San Joaquin Valleys. The Alexander Commission produced the first systematic hydrologic overview of the Central Valley, which promoted a perspective of the river basin as a coordinated system (Alexander et al. 1874; Pisani 1984; Kelley 1989). Subsequently, Alexander advocated a centrally controlled single-channel system as used on the Mississippi River and detailed in the Humphrey and Abbot (1861) report to Congress. This approach was vigorously supported by large landowners in Butte, Sutter, and Colusa Basins who sought to protect vast holdings of low-lying lands from flooding. Between these landowners and the strong singlechannel tradition within the engineering community, a powerful coalition developed around a flood-control policy focused on holding flood waters within main channels with large levees. This policy was encouraged by the immediate need to control sedimentation of rivers, and opposition to government involvement in river management beyond navigation improvements. Consequently, the goal of flood control for much of the late 19th century was to extend, strengthen, and grade a coordinated system of levees with narrow spacings along major rivers and their tributaries, and to dam crevasses that distributed flows to sloughs and basins. While these tactics became the government policy, implementation was hampered by limited funds to cover the tremendous expense of building such a system.

One exception to a single-channel flood-control strategy was in the lower Yuba River. Due to the massive amount of hydraulic mining sediment produced in the Yuba basin, the lower river quickly developed extensive deposits with a multithread channel system (Fig. 4). As a coordinated system of levees was introduced on the Yuba, they were spaced far apart to encourage sediment retention on floodplains, rather than allowing sediment to be delivered farther down to the navigable Feather and Sacramento Rivers. With wide levee spacings, the main Yuba channel was prone to sedimentation, so scour was encouraged by the construction of coarse bouldery wing dams that narrow in-channel flows. The spacing of levees gets narrow near the confluence of the Yuba with the Feather River, which encourages sediment retention but increases local flood hazards. To this day, the lower Yuba River has a master low-water channel and a series of distributary highwater channels. In contrast, the Bear River was engineered with narrow levee spacings through the lower $18 \mathrm{~km}$, but sediment retention was encouraged further upstream above the narrow levees.

\section{Sediment Detention Dam Failures}

A key to the single-channel strategy was control of the hydraulic mining sediment that continued to be produced in the mountains during the 1870 s. Sedimentation during floods threatened catastrophic failures to even the most robust flood-control structures and remained a menace to navigation. The government strategy for controlling mining sediment, based on united support from farmers and miners, was to construct brush dams on the major rivers to detain the coarse fraction of sediment from the mines (Kelley 1956) and the plan was to reinforce these brush dams later with larger, more substantial structures. Brush dams were built on the lower Bear and Yuba Rivers in 1880, but both failed by 1882 (Mendell 1881, 1882). The brush dam on the lower Bear River had an average height of $1.8 \mathrm{~m}$ and quickly filled with $735,000 \mathrm{~m}^{3}$ of sediment before it breached. The brush dam on the Yuba River had an average height of $2.1 \mathrm{~m}$ and filled with $3,700,000 \mathrm{~m}^{3}$ of sediment by 1882 .

In 1904, a gravel and stone dam, known as Barrier No. 1, was begun on the lower Yuba River (Gilbert 1917). The first stage of construction drove pilings into the river gravels and raised a dam $1.8 \mathrm{~m}$ high, which backfilled with sediment the following winter. The following year, pilings were driven into the new sediment and the dam was raised another $2.4 \mathrm{~m}$, and this reservoir also quickly filled with sediment. In total, Barrier No. 1 impounded $1,292,000 \mathrm{~m}^{3}$ before being destroyed by a flood in 1907, when most of the sediment was quickly eroded (Gilbert 1917). It was not until Daguerre Point dam was completed in 1910 that the first attempt to restrain mining sediment was successful. This dam, located $7 \mathrm{~km}$ downstream of the Barrier No. 1 site and $16 \mathrm{~km}$ upstream from the mouth of the Yuba River, had a spillway cut into a bedrock spur and lined with concrete. Bedrock outcrops are rare in these lower alluvial reaches, so this strategy was not generally applicable elsewhere.

The repeated dam failures for the 30 years from 1880 to 1910 cast doubt on the viability of contemporary dam technology and the ability to prevent hydraulic mining sediment from reaching the lower valley. These doubts reinforced the policy of relying on levees to hold the entire flow rivers within main channels and to maximize flood depths and scour.

\section{Coordinated River-Basin Management and a Bypass System}

By the turn of the twentieth century, levee failures had continued to generate catastrophic losses during frequent flood events. Flood control remained fragmented in numerous local levee and reclamation districts, and funding was limited for the enormous investment needed for a coordinated valley-wide levee system. Flooding was such a hazard in some basins that it affected the viability of farming and settlement of large areas. For example, settlement in Sutter and Yuba Counties had lagged behind other counties due to the persistent threat of deep, high-velocity floods (Kelley 1965, 1989). Frustration with frequent flooding had grown and critiques of the long-held single-channel policy became commonplace. The need for an alternate vision was inescapable.

In response to the changing political culture and increasing knowledge of physical conditions, public attitudes toward flood control in California became increasingly open to a centrally designed and managed flood-control system (Kelley 1989). The pro- 


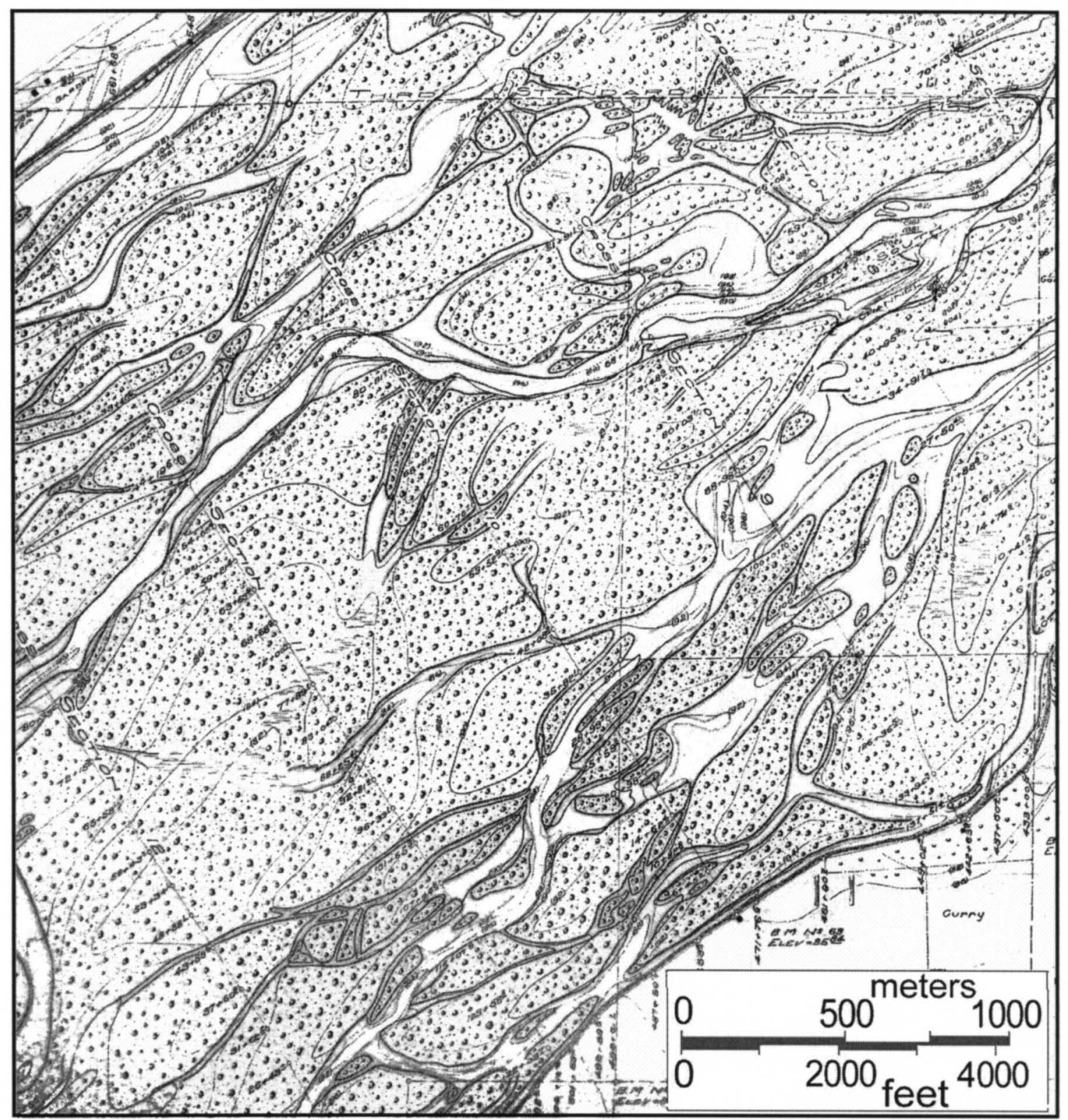

Fig. 4. 1906 map of lower Yuba River showing wide levee setbacks and multithread channel system that resulted from deep, historical aggradation. Flow is from upper right to lower left [adapted excerpt from CDC (1906)].

gressive era and the conservation movement led to greater acceptance of government involvement in the scientific management of resources (Hays 1959). Local and professional experience had demonstrated the need for a coordinated multichannel system that allowed main channels to overflow into the basins during floods. The time was rife with calls for a major change in floodmanagement policy, but it would require a shift to a centralized management system that did not yet exist.

\section{California Debris Commission and the Jackson Plan}

In response to a national economic recession, the soaring value of gold, and political pressure from miners near the end of the 19th century, Congress sought to revitalize the hydraulic gold-mining industry in California. In 1893, the Caminetti Act was passed, which allowed hydraulic gold mining to resume under the condi- tion that sediment would be detained near the mines and prevented from delivery to navigable rivers. This act did not succeed in reinstating the hydraulic gold mining industry, but it created the California Debris Commission (CDC) associated with the COE to administer a licensing program for hydraulic mining (Kelley 1959). As a permanent governing body with regulatory powers, the CDC can be regarded as the first river basin commission in the west (Kelley 1965, 1989), and this began a period of state and federal cooperation that had not previously existed (Mitchell 1994). Congress explicitly gave the CDC the authority to manage flood control at a time when COE jurisdiction was confined to navigation. This authority was not initially utilized, as the CDC concentrated primarily on the navigability of the Sacramento River system independently of flood hazard issues. Moreover, the CDC was underfunded for the first several years of its existence (Hagwood 1981). After 1910, however, the broad authority 
granted by Congress to the CDC came into play as the Commission advocated for a multichannel flood-control system in the valley (Kelley, 1989).

Although Will Green had lobbied for a multichannel system with a coordinated system of levee protection as early as the 1860s, the idea had been ahead of its time (Kelley 1989). Several factors had changed by the 1890 s, however, and the public was ready for a change. In 1894, the Manson-Grunsky Report (CCPW 1895) presented a detailed plan for a multichannel bypass system based on numerous measurements that had been collected over the previous quarter century, including surveys of the State Engineer (Hall 1880), the Alexander Commission report, stream gauging, and supporting studies by the CDC. The result was a new understanding of the rivers as physical systems with specific hydrologic and sedimentary characteristics. The Manson-Grunsky plan proposed a bypass system, using a series of control weirs to route Sacramento River flood flows out of the main channel through a system of channelized and leveed "bypasses" built within existing flood basins. The bypasses would be activated only during large floods and the majority of the basin lands would be protected from flooding, allowing farming activities in most of the basin area to continue unabated.

The system advocated by the Manson-Grunsky report was a major departure from the long-held policy of a single-channel system. It retained a heavy reliance on levees to contain moderate magnitude floods and to carry sediment in deep narrow channels. However, it could manage large floods that had previously been uncontrollable within the main channel. The concrete weirs would allow distributary flows to enter bypasses during floods, but would prevent crevasse deepening that could otherwise allow moderate flood events to pass into the basins. Although the bypass system would not be built for many years, public and professional opinion was fundamentally changed after the Manson-Grunsky report with respect to a multichannel policy that utilized basins for conveyance (Kelley 1989).

As is often the case, it took a large flood catastrophe to generate the political will and public support for the necessary funds and authorization to develop a coordinated flood-control system. In this case, it was a pair of floods in the valley: a devastating 1907 flood followed by another in 1909 catalyzed state support for a state-wide flood-control plan. Shortly after, in 1910, Captain Thomas Jackson, a CDC Commissioner, put forth a report (CDC 1911) advocating a flood-control plan that closely resembled the Manson-Grunsky plan. The Jackson Plan, as it became known, enlarged the bypasses to facilitate larger flows than had been specified in the Manson-Grunsky report, but in most other respects the two plans were similar (Kelley 1989). A strong navigation bias was retained in the Jackson Plan, and narrow levee spacings were designed to promote scouring of channels. The project would require an estimated $320 \mathrm{~km}$ (200 miles) of levees along main rivers plus an additional $480 \mathrm{~km}$ (300 miles) of levees along tributaries and sloughs. The bypasses advocated by the Jackson Plan were to follow the deepest troughs of the basins. For political reasons, the route of the Sutter Bypass was subsequently shifted to a higher, more easterly course than the original plan, however, so that it now joins the Feather River well above the Sacramento River and at a lower gradient (Ellis 1939, p. 171). Due to the recent failure of the debris dams on the Yuba and Bear Rivers and to limited capacities of contemporary reservoir technology, dams were not included in the plan. The Jackson Plan was adopted by the California Legislature in 1911 who created the State Reclamation Board to implement it.

Such an immense project clearly required federal financial as- sistance to become a reality, but Congressional approval for crucial levels of federal-state cost sharing was slow to materialize. The CDC was vested with broad powers at a time initially before the jurisdiction of the $\mathrm{COE}$ was to be expanded from navigation to flood control and flood relief. The CDC began to use its broad authority to advocate the Jackson Plan to Congress and thereby expand the authority of the COE. By the 1920s, a single, deep channel was no longer seen as essential. Hydraulic mining had been curtailed for long enough that many valley channels had ceased aggrading. In fact, many valley channels were noticeably incising in response to the halt in sediment production from hydraulic mining, to the success of the narrow levee spacings in deepening flows, and to dredging downstream. Dredging across Horseshoe Bend in the lower Sacramento River below Rio Vista, for example, began in 1913 and removed more sediment than had been removed by the excavation of the Panama Canal. By 1927, largely in response to dredging near the mouth of the Sacramento River, channel incision had progressed upstream to Sacramento where low-flow river stages had dropped 3 m since 1905 (Gilbert 1917; Kelley 1989).

The Jackson Plan was adopted at the federal level when Congress passed the Flood Control Act (U.S. Congress 1917). This Act initiated the Sacramento River Flood Control Project (SRFCP) and authorized initial funding, predicated on 50-50 costsharing with the State (NRC 1995), for construction of levees, weirs, and bypasses in the Sacramento Valley. This was the first instance of Congressional appropriations made openly and primarily for flood control (Arnold 1988). Construction on the SRFCP began in 1918; by 1944, $90 \%$ of the project had been constructed, and it was completed in 1968 after the closure of Oroville Dam. From the 1940s through the 1970s, the SRFCP was augmented with several large, multipurpose dams, which are now an integral part of the system.

\section{Resulting System}

The SRFCP includes approximately $1,760 \mathrm{~km}$ (1,100 miles) of levees and a series of bypass channels, connected to the Sacramento River by five overflow weirs. Four of the weirs have a fixed stage (Moulton, Colusa, Tisdale, and Fremont) and the fifth is gated (Sacramento) (Table 2, Fig. 5). By the mid-twentieth century, a multigovernmental flood-control arrangement had evolved in which the CDC represented the federal government, the State Reclamation Board represented the state, and the State Association of Reclamation Districts represented the people (Kelley 1989). To be accurate, the SRFCP should be considered within the larger integrated water resources management context of the Central Valley Project and the California Water Plan. The water-resources systems that have evolved in the valley consist of much more than flood control. They are part of an integrated river basin system that includes a series of federal, state, and local dams, canals, power plants, and pumping plants to store spring snowmelt and deliver it throughout the Central Valley to southern California, and through the Sacramento-San Joaquin Delta.

Reservoir operation is essential to managing flood waters in the valley insofar as they can truncate critical peak discharges during floods. Reservoir operations are coordinated by the California-Nevada River Forecast Center (CNRFC) in Sacramento. The California Department of Water Resources and the National Weather Service (NWS) collaborate to provide flood forecasting and flood warnings. The system includes precipitation forecasts, observations from telemetered rainfall and streamflow gages, snowpack water content, and other hydrologic data that are 
Table 2. Weirs in Sacramento Flood-Control Project [Adapted from CDWR (2003)]

\begin{tabular}{|c|c|c|c|c|c|c|}
\hline Weir & $\begin{array}{l}\text { Year } \\
\text { built }\end{array}$ & Type & $\begin{array}{l}\text { Length } \\
(\mathrm{m})\end{array}$ & $\begin{array}{l}\text { Capacity } \\
(\mathrm{cms})\end{array}$ & $\begin{array}{l}\text { Releases } \\
\text { to }\end{array}$ & Comments \\
\hline Moulton & 1932 & Concrete & 500 & 708 & Butte Basin & Left bank Sacramento River $\sim 13 \mathrm{~km}$ above Colusa. \\
\hline Colusa & 1933 & Concrete & 1,650 & 1,982 & $\begin{array}{c}\text { Colusa and } \\
\text { Sutter Basins }\end{array}$ & Left bank Sacramento River $\sim 1.6 \mathrm{~km}$ above Colusa. \\
\hline Tisdale & 1932 & Concrete & 1,150 & 1,076 & Tisdale Bypass & $\begin{array}{l}\text { Left bank Sacramento River; connects to Sutter Bypass via } \\
\qquad 7 \mathrm{~km} \text { long Tisdale Bypass. }\end{array}$ \\
\hline Fremont & 1924 & Concrete & 10,560 & 9,713 & Yolo Bypass & $\begin{array}{c}\text { Right bank Sacramento River; some Sutter Bypass flow } \\
\text { crosses to Yolo Bypass. }\end{array}$ \\
\hline Sacramento & 1916 & 48 gates & 1,920 & 3,171 & $\begin{array}{l}\text { Sacramento } \\
\text { Bypass }\end{array}$ & $\begin{array}{c}\text { Right bank Sacramento River; connects to Yolo Bypass via } \\
1.5 \mathrm{~km} \text { Sacramento Bypass. Gates operated manually. } \\
\text { Reverse flow up Sacramento River possible when } \\
\text { American River is in flood. }\end{array}$ \\
\hline Cache Creek & $1991^{\mathrm{a}}$ & Concrete & 1,740 & 850 & Yolo Bypass & $\begin{array}{c}\text { Primarily for tributary sediment detention rather than flood } \\
\text { control. }\end{array}$ \\
\hline
\end{tabular}

${ }^{\mathrm{a}}$ Originally constructed between 1930s and 1950s; new weir completed in 1991.

loaded into the California Data Exchange Center digital system (Roos 2006). Forecasting by the system utilizes the NWS River Forecasting System. Although flood forecasting and reservoir operating policies receive considerable scrutiny, the heart of the SRFCP is the bypass system, which predates the reservoirs and carries tremendous volumes of flood water. At Sacramento, 82\% of flood discharges typically passes through the Yolo bypass, while only $18 \%$ flows through the main channel (Roos 2006). An analysis of ratios of reservoir capacities to mean annual floods indicates that the effectiveness of flood control by foothill dams is limited in the lower Sacramento River (Singer 2007). Instead, the lower basin relies heavily on the weir and bypass system to control flooding and this system requires attention.

In recent decades, three factors have driven up flood hazards in the lower Sacramento Valley:

- Climate change;

- Urbanization of low-lying lands; and

- Inadequacies of the flood-control system.

The potential effects of climate change on flood hazards in the valley go beyond the scope of this review. Briefly, the magnitude of early spring runoff is increasing (Aguado et al. 1992; Dettinger and Cayan 1995; Shelton 1998; Knowles and Cayan 2004), and flood magnitudes and frequencies may be larger.

Escalating suburban development in the flood basins has been of growing concern and often concentrates on former agricultural lands for which the levee system is not adequately designed. Present state policies for levees are based on the 100-year flood stage for levees protecting agricultural areas, and the 200-year flood stage for urban areas. Thus, changes in land-use patterns pose a number of problems including the inability of the system to provide adequate flood protection and state liability for flood losses (CDWR 2005). Policy toward real estate development on floodplains is in flux in California. A recent appellate court case (Paterno v. State of California, 113 Cal. App. 4th 998, 2003) held the State liable for flood losses due to failure of a SRFCP levee at the mouth of the Yuba River. A flurry of levee improvements ensued, and new state flood legislation was signed into law in 2007 to shift liability to local governments for irresponsible development of low-lying lands.

The 50-year old flood protection system has serious flaws in its physical condition and is in dire need of repair and maintenance. Design deficiencies date to the original construction materials and foundations established during the mining era that may permit underseepage and failures. In addition, deferred mainte-

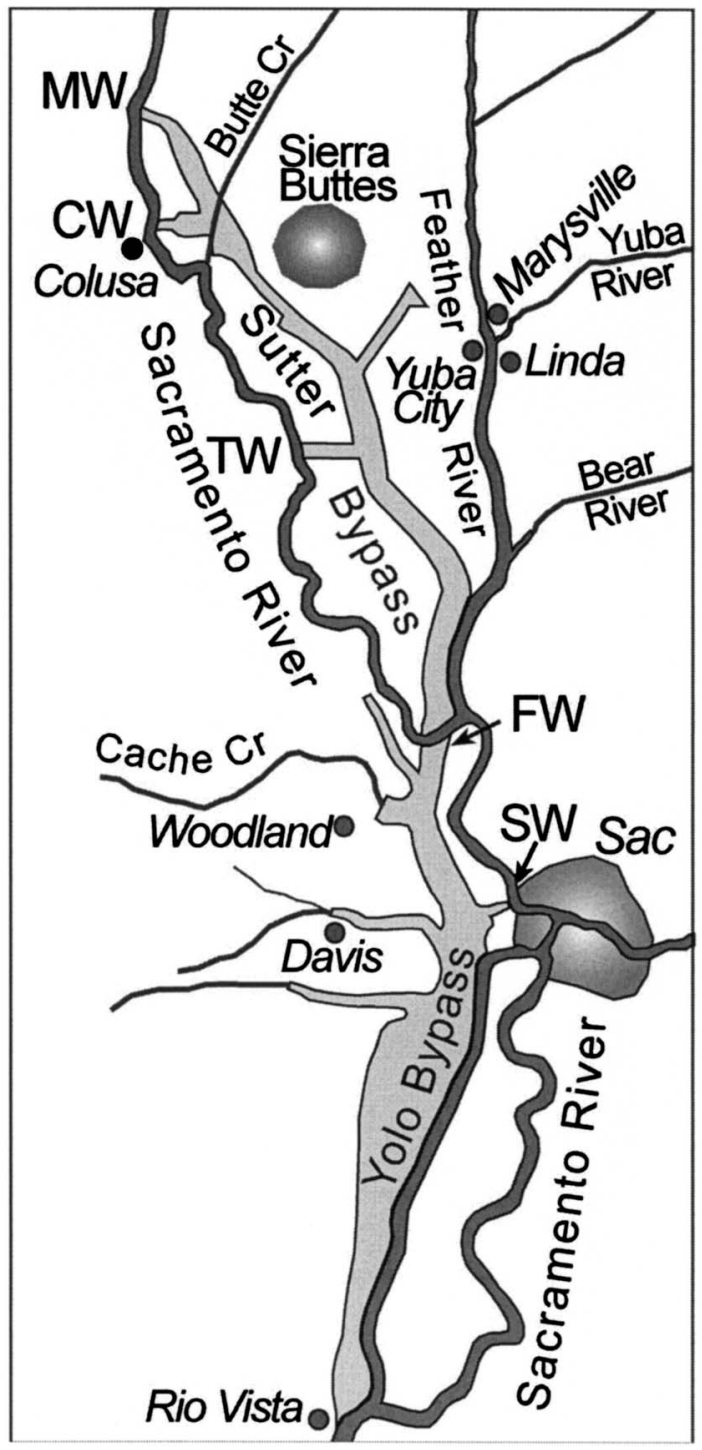

Fig. 5. Flood bypass system as built. Originally envisioned by Manson-Grunskey report and slightly revised by Jackson Plan. $\mathrm{MW}=$ Moulton Weir; $\mathrm{CW}=$ Colusa Weir; TW=Tisdale Weir; $\mathrm{FW}=$ Fremont Weir; $\mathrm{SW}=$ Sacramento Weir. Sac $=$ City of Sacramento [adapted from Kelley (1989)]. 
Table 3. Budget and Phase of Development for Levee Improvements on Lower Bear, Yuba, and Feather Rivers [Data Adapted from TRLIA (2006, 2007)]

\begin{tabular}{lccl}
\hline & Cost & $\begin{array}{c}\text { Year } \\
\text { completed }\end{array}$ & \multicolumn{1}{c}{ Nature of project } \\
\hline Phase 1 & $4,758,341$ & 2004 & $\begin{array}{l}\text { Repair/improve Yuba River levees that failed in 1986 flood. } \\
\text { Repair/improve levees on Bear River, Western Pacific } \\
\text { Phase 2 }\end{array}$ \\
& $29,002,957$ & 2005 & $\begin{array}{l}\text { Interceptor Canal (near Bear River), and Yuba River (short } \\
\text { section). }\end{array}$ \\
Phase 3 & & 3.2 km levee setback on Bear River. \\
Phase 4 (Yuba) & $67,259,674$ & 2006 & Another short section of Yuba River levees. \\
Phase 4 (Feather) & $28,555,130$ & 2006 & Feather River setbacks on east bank between Star and \\
Shanghai Bends. & \\
Olivehurst & $121,926,303$ & TBA & \\
Detention Basin & & & \\
Interim O\&M & $8,536,432$ & & \\
Total & $2,100,000$ & & \\
\hline
\end{tabular}

nance of the aging system has allowed levees to deteriorate substantially from erosion and growth of vegetation (CDWR 2005). Clearing sediment from bypasses may also be needed, especially in the Sutter and Yolo bypasses below the Feather River where reworking of hydraulic mining sediment appears to be substantial (James et al. 2007).

In the aftermath of the Hurricane Katrina disaster in New Orleans, the condition of levees in the Sacramento Valley has come under increasing scrutiny. Even before Katrina, the integrity of some levees had come into question. Between 1989 and 2003, the COE investigated flood control levees along $1,700 \mathrm{~km}$ of river in the SRFCP and found $142 \mathrm{~km}$ that needed significant repairs (CDWR 2005). For example, near the lower Bear River, portions of the levees lacked the $0.9 \mathrm{~m}(3 \mathrm{ft})$ of freeboard above the $1 \%$ chance flood stage that the Federal Emergency Management Agency (FEMA) requires for levee certification (44 CFR 1 $\$ 65.10)$. The affected areas in Yuba County, including the Plumas Lake housing development, were mapped in the special flood hazard area (SFHA) by FEMA. Such a change in designation subjects many local landowners to floodplain regulations, constraints on building permits, and substantial increases to federal flood insurance rates.

Subsequently, in 2004 the Three Rivers Levee Improvement Authority (TRLIA) was created by Yuba County and Reclamation District 784 to develop levee-improvement plans for the lower Feather, Yuba, and Bear Rivers. This prompted two major levee set-back projects that are now in various stages of completion or design. Funding for these projects is expected to reach $\$ 262$ million (Table 3), which has been or is being raised through a combination of a FEMA Federal Emergency Management Grant, state funds, county funds, and contributions from developers (TRLIA 2006).

If we are to learn from the past, levee improvement programs should be coupled with disincentives to further development in low-lying areas behind levees. Instead, new housing is springing up behind levees in some of the topographically lowest positions in the area. For example, almost 12,000 homes are proposed for the Plumas Lake area (Marysville Appeal-Democrat-March 20, 2004), a topographically low position along the lower Feather River. As of June 1, 2007, 1,600 building permits had been issued for this development (TRLIA 2007).

\section{Conclusions}

This brief history of flood control in the Sacramento Valley outlines the hydrogeomorphic conditions and political changes that underlay the development of a flood bypass system in the valley. The bypass system reduces flood hazards insofar as it controls the geographic extent of frequent inundations of low-lying basins and designates specific floodplain areas where overflow is allowed during high flood stages. The system has been successful in achieving the initial goals of protecting large areas of low-lying agricultural lands from frequent floods by limiting the geographic extent of frequent fooding and preventing development in the bypass areas. In some cases, lack of maintenance, ongoing channel erosion, and recent land-use developments have resulted in conditions in which levees may not provide a suitable level of protection.

Initial levees in the valley were not well planned because they began with little knowledge of flow regime or frequencies of inundation in the valley. They were built quickly to stop flooding and sedimentation as settlements grew rapidly along rivers and lowlands. System-wide planning began to be adopted in the late 19th century. It was initially based on a policy of retaining all flows within the master channels using levees with narrow spacings in order to encourage scour of the massive sediment loadings from hydraulic mining. Although levees were strengthened, extended, and partially graded under this centralized policy, flooding continued. The single-channel policy ultimately failed because the Sacramento channel lacks the capacity to contain the large magnitude floods that are delivered. Low-lying basins had always provided a broad, natural distributary channel system that carried the bulk of the flow during large floods. Shutting off the crevasses that fed these basins forced too much flow into the main channel.

Ultimately, the need for a bypass system modeled on the 1894 Manson-Grunsky and 1910 Jackson plans was recognized. The policy of federal support for flood control that emerged in the USA during the early 20th century was first implemented in the Mississippi and Sacramento River basins. The California Debris Commission (CDC) was created by Congress in 1893 with the rare authority to facilitate not only navigation, but also flood control. This authority later became instrumental in gaining Congressional approval of an extensive flood-control system in the Central Valley. The current levee-bypass system began to be implemented in 1918 and was completed in the 1960s. It has been successful in constraining the extent of deep inundation, but cannot always prevent flooding behind levees. The costs and dimensions of the required levee system continue to escalate as land use intensifies behind the levees and design flaws persist as a legacy of the hydraulic mining era. Ongoing development of basin lands suggests that public expectations for flood-risk reduction by this 
system are unrealistic and sudden levee failure could be catastrophic. Standard floodplain management strategies are needed that develop public awareness of the hazard, economic disincentives for irrational development, and contingency plans for disaster mitigation. More attention is needed to the physical system including levee improvements and maintenance and sediment removal from bypasses.

\section{Acknowledgments}

This paper would not have been possible without the extensive writings and insights of the late Robert Kelley. His early writings on hydraulic mining sediment-Gold versus Grain (Kelley 1959) — and his treatise_Battling the Inland Sea (Kelley 1989)_ are crucial to an understanding of this history and were relied on heavily for this summary. The University of California, Davis map library provided the historical map in Fig. 4. Subhajit Ghoshal helped scan maps. The writers have benefited greatly from funding provided by the National Science Foundation, Award Nos. BCS 0520933 and 0521663. Part of this research was performed while Singer held a National Research Council Research Associateship Award at USGS Menlo Park. Two anonymous reviews provided helpful comments that led to substantial improvements of an early draft.

\section{References}

Aguado, E., Cayan, D. R., Riddle, L., and Roos, M. (1992). "Climatic fluctuations and the timing of west coast streamflow." J. Clim., 5(12), $1468-1483$.

Alexander, B. S., Mendell, G. H., and Davidson, G. (1874). Report of the Board of Commissioners on the Irrigation of the San Joaquin, Tulare, and Sacramento Valleys of the State of California, Government Printing Office, Washington, D.C.

Arnold, J. L. (1988). "Evolution of the 1936 flood control act." EP 8701-29, Office of History, U.S. Army Corps of Engineers, Fort Belvoir, Va.

Bryan, K. (1923). "Geology and ground-water resources of Sacramento Valley, California.” Water Supply Paper No. 495, U.S. Geological Survey.

California Commissioner of Public Works (CCPW). (1895). Report to the Governor of California, 1983-1894, Appendix to Journal of Senate and Assembly of the 31st Session of the Legislature, Sacramento, Calif.

California Debris Commission (CDC). (1906). "Map of the Yuba River California from the Narrows to its mouth in the Feather River." Sheet 2; scale: 1:9600.

California Debris Commission (CDC). (1911). Report on the Control of Floods in the River Systems of the Sacramento Valley and the Adjacent San Joaquin Valley, California. U.S. House Doc. 81, 62nd Congr., 1st Sess.

California Department Water Resources (CDWR). (2003). "Sacramento River flood control project weirs and flood relief structures." Fact Sheet, California Department of Water Resources, Division Flood Management.

California Department Water Resources (CDWR). (2005). "Flood warnings: Responding to California's flood crisis."〈http://www.public affairs.water.ca.gov/newsreleases/2005/01-10-05flood-warnings.pdf $\rangle$ (Mar. 10, 2008).

Crawford, J., and Herrick, J. (2006). "Intelligent engineering: William Hammond Hall and the State Engineering Department." Sacramento History J., 1(1-4), 133-160.

Dettinger, M. D., and Cayan, D. R. (1995). "Large-scale atmospheric forcing of recent trends toward early snowmelt in California." $J$.
Clim., 8(4), 606-623.

Ellis, W. T. (1939). Memories: My seventy-two years in the romantic county of Yuba, California, University of Oregon Press, Eugene, Ore.

Fenneman, N. M., and Johnson, D. W. (1946). "Physiographic divisions of the conterminous U.S.” U.S. Geological Survey, Washington, D.C.

Gilbert, G. K. (1917). "Hydraulic mining débris in the Sierra Nevada, California.” Professional Paper 105, U.S. Geological Survey.

Greenland, P. (2001). Hydraulic mining in California: A tarnished legacy, Arthur H. Clark Co., Spokane, Wash.

Hackell, O. (1966). "Summary of the geology of the Great Valley." Geology of Northern California, Bull. 190, E. H. Bailey, ed., Calif. Div. Mines and Geology, San Francisco, 217-238.

Hagwood, J. J., Jr. (1981). The California debris commission: A history of the hydraulic mining industry in the western Sierra Nevada of California, and of the governmental agency charged with its regulation, U.S. Army Corps of Engineers, Sacramento, Calif.

Hall, W. H. (1880). "Report of the state engineer to the Legislature of California." Calif. Printing Office, Sacramento, Calif.

Hays, S. P. (1959). Conservation and the gospel of efficiency: The progressive conservation movement, 1890-1920, Harvard University Press, Cambridge, Mass.

Heuer, W. H. (1891). "Improvement of San Joaquin, Mokelumne, Sacramento and Feather Rivers, Petaluma Creek, and Humboldt Harbor and Bay, California." Report of Major W. H. Heuer, Appendix VV, House Doc. 1, Part 2, 52nd Congress, 1st Session, 2980-3118.

Humphrey, A. A., and Abbot, H. L. (1861). Report upon the Physics and Hydraulics of the Mississippi River; upon the Protection of the Alluvial Region against Overflow; and upon the Deepening of the Mouths, Bureau of Topographic Engineers, War Dept., U.S. Government Printing Office, Washington, D.C.

James, L. A. (1989). "Sustained storage and transport of hydraulic mining sediment in the Bear River, California." Ann. Assoc. Am. Geogr., 79(4), 570-592.

James, L. A. (1999). "Time and the persistence of alluvium: River engineering, fluvial geomorphology, and mining sediment in California." Geomorphology, 31, 265-290.

James, L. A., Singer, M. B., and Aalto, R. (2007). "Field trip guide and road log: Tracking hydraulic mining sediment in the Sierra Foothills and Sacramento Valley.” Proc., Annual meeting Assn. Amer. Geographers in San Francisco.

Kelley, R. L. (1956). "The mining debris controversy in the Sacramento Valley, California." Pacific Historical Review, 25(4), 331-346.

Kelley, R. L. (1959). Gold vs. grain: The hydraulic mining controversy in California's Sacramento Valley, Arthur Clark Co., Glendale, Calif.

Kelley, R. L. (1965). "Taming the Sacramento: Hamiltonianism in action." Pacific Historical Review, 34(1), 21-49.

Kelley, R. L. (1989). Battling the inland sea: American political culture, public policy, and the Sacramento Valley, 1850-1986, Univ. Calif. Press, Berkeley, Calif.

Keyes (1878). "Keyes vs. Little York Gold Washing Co. et al.” Calif. District Court, 10th District, Sutter County, Judge Philip Keyser.

Knowles, N., and Cayan, D. R. (2004). "Elevational dependence of projected hydrologic changes in the San Francisco Estuary and watershed." Clim. Change, 62(1/3), 319-336.

Mendell, G. H. (1881). "Protection of the Navigable water of California from injury from the débris of mines." Report of the Chief of Engineers, U.S. Army, Appendix MM7; House Doc. 76; 46th U.S. Congress, 3rd Session.

Mendell, G. H. (1882). "Report upon a project to protect the navigable waters of California from the effects of hydraulic mining." House Doc. 98; 47th Congress, 1st Session.

Mitchell, M. D. (1994). "Land and water policies in the Sacramento-San Joaquin Delta.” Geogr. Rev., 84(4), 411-423.

National Research Council (NRC). (1995). Flood risk management and the American River basin: An evaluation, National Academy Press, Washington, D.C. 
National Research Council (NRC). (1999). Improving American River flood frequency analyses, National Academy Press, Washington, D.C.

O'Neill, K. M. (2006). "Levee troubles: The cost of making the Sacramento Valley into an agricultural giant." Sacramento History J., 1(14), 73-104.

Pisani, D. J. (1984). From the family farm to agribusiness: The irrigation crusade in California and the West, 1850-1931, University Calif. Press, Berkeley, Calif.

Roos, M. (2006). "Flood management practice in northern California." Irrig. Drain., 55(S1), S93-S99.

Sacramento Area Flood Control Agency (SAFCA). (2008). "Sacramento flood risk." 〈http://www.safca.org/floodRisk/floodThreat.html〉 (Mar. 10, 2008)

Shelton, M. L. (1998). "Seasonal hydroclimate change in the Sacramento River basin, California." Phys. Geogr., 19(3), 239-255.

Singer, M. B. (2007). "The influence of major dams on hydrology through the drainage network of the Sacramento River Basin, California." River Research and Applications, 23(1), 55-72.

Singer, M. B., Aalto, R., and James, L. A. (2008). "Status of the lower Sacramento Valley flood-control system within the context of its natural geomorphic setting." Nat. Hazards Rev., 9(3).
Thompson, K. (1960). "Historic flooding in the Sacramento Valley." $P a$ cific Historical Review, 29(4), 349-360.

Thompson, K. (1961). "Riparian forests of the Sacramento Valley, California.” Ann. Assoc. Am. Geogr., 51(3), 299-315.

Three Rivers Levee Improvement Authority (TRLIA). (2006). "TRLIA 2006/07 budget; approved by TRLIA, July 11, 2006.” 〈http://www. trlia.org/> (Sept. 10, 2007).

Three Rivers Levee Improvement Authority (TRLIA). (2007). "TRLIA project status report; June 1, 2007." Submitted to State Reclamation Board, 〈http://www.trlia.org/〉 (Sept. 10, 2007).

U.S. Army Corps of Engineers (USACE). (1998). "Post-flood assessment for 1983, 1986, 1995, and 1997, Central Valley, California." Sacramento District, Sacramento, Calif.

U.S. Congress. (1917). "Flood control act. An act to provide for the control of the floods of the Mississippi River and of the Sacramento River, Calif., and for other purposes." 64th Congress, Sess. 2, Ch. 144.

U.S. Geological Survey (USGS). (2007). "Sacramento River Basin NAWQA: Environmental setting.” 〈http://ca.water.usgs.gov/sacnawqa/enviroset.html (July 12, 2007). 